\title{
Hyperthermia During Intraperitoneal Chemotherapy With Paclitaxel or Docetaxel for Ovarian Cancer: Is There Any Benefit?
}

\author{
EELCO DE BREE ${ }^{1}$, DESPOINA KATSOUGKRI ${ }^{2 *}$, HARA POLIOUDAKI ${ }^{2 *}$, ELENA TSANGARIDOU ${ }^{2 *}$, \\ DIMOSTHENIS MICHELAKIS ${ }^{1}$, ODYSSEAS ZORAS ${ }^{1}$ and PANAYIOTIS THEODOROPOULOS ${ }^{2}$ \\ ${ }^{1}$ Department of Surgical Oncology, Medical School of Crete University Hospital, Heraklion, Greece; \\ ${ }^{2}$ Department of Biochemistry, Medical School of Crete, Heraklion, Greece
}

\begin{abstract}
Background/aim: Intraperitoneal chemotherapy with taxanes provides high locoregional drug concentrations. Regarding their synergy with hyperthermia, results have been inconclusive. In this in vitro study, the thermal enhancement of the effect of paclitaxel and docetaxel on ovarian cancer cells under conditions mimicking those during hyperthermic intraperitoneal chemotherapy (HIPEC) is evaluated. Materials and Methods: Cisplatin-resistant SKOV-3 and OVCAR-3 ovarian cancer cells were exposed for $2 h$ to $0.1,1$ and $3 \mu M$ of paclitaxel and docetaxel at $37^{\circ} \mathrm{C}$ (normothermia) and $41.5^{\circ} \mathrm{C}$ (hyperthermia). Cell proliferation and cell-cycle distribution were evaluated after $24 h, 3$ days and 7 days. Results: A concentration-dependent cytotoxic effect on cell proliferation was observed. Concurrent hyperthermia caused an increased arrest of cells in the $G_{2} / M$ phase. At 7 days, thermal enhancement of drug effect was shown only for treatment of OVCAR-3 cells with $1 \mu M$ paclitaxel. Conclusion: The concentration-dependent cytotoxic effect of paclitaxel and docetaxel supports their intraperitoneal use. Due to the lack of or only minimal thermal enhancement, normothermic may be as effective as hyperthermic intraoperative intraperitoneal chemotherapy with taxanes, avoiding, however, potential oncological and treatmentrelated adverse effects of concurrent hyperthermia.
\end{abstract}

This article is freely accessible online.

*These Authors contributed equally to this study.

Correspondence to: Eelco de Bree, MD, Ph.D., Department of Surgical Oncology, University Hospital, P.O. Box 1352, 71110 Heraklion, Greece. Tel: +30 2810392056/392382, Fax: +30 2810392382, e-mail: debree@edu.uoc.gr

Key Words: Paclitaxel, docetaxel, hyperthermia, ovarian cancer, in vitro study, intraperitoneal chemotherapy, HIPEC.
After cytoreductive surgery (CRS) for advanced ovarian cancer, inevitably at least residual microscopic peritoneal disease is left behind, which remains to be eliminated by chemotherapy. The taxanes paclitaxel and docetaxel are effective agents in the treatment of ovarian cancer by binding to and promoting the assembly of tubulin into dysfunctional microtubules, resulting in inhibition of mitosis and cell proliferation, and consequently the death of rapidly proliferating tumor cells $(1,2)$. The degree of exposure to paclitaxel and docetaxel is known to correlate with treatment response $(1,2)$. Intraperitoneal chemotherapy for residual peritoneal disease provides an evident pharmacokinetic advantage over intravenous chemotherapy, with high locoregional and simultaneously low systemic drug exposure. Paclitaxel and docetaxel have a highly favorable pharmacokinetic profile after intraperitoneal administration, mainly due to their high molecular weight and hydrophobic properties which delay absorption from the abdominal cavity (3, 4). Intraperitoneal chemotherapy with taxanes have been demonstrated to be effective in advanced ovarian cancer $(5,6)$. A prerequisite for effective intraperitoneal chemotherapy is optimal CRS, leaving no or only very small peritoneal metastases behind, since the penetration depth of intraperitoneally delivered drugs is limited. The intraoperative application of intraperitoneal chemotherapy directly after CRS prohibits inadequate exposure of the entire seroperitoneal surface to the drug solution due to formation of adhesions and allows early treatment before tumor regrowth occurs (7). CRS and hyperthermic intraoperative intraperitoneal chemotherapy (HIPEC) have been increasingly used in the treatment of primary and secondary peritoneal malignancies, including advanced ovarian cancer $(8,9)$.

The rationale for performing intraoperative intraperitoneal chemotherapy under hyperthermic conditions is that hyperthermia itself is considered cytotoxic and it enhances the cytotoxicity, as well as the tissue penetration, of many chemotherapeutic drugs $(4,7,10-12)$. The target intraabdominal temperature is usually between 40 and $42^{\circ} \mathrm{C}$ for 30 
to 120 minutes, according to the center's protocol. Local temperatures of $43^{\circ} \mathrm{C}$ and higher may cause thermal injury to organs and other tissues (13). Although for platinum compounds thermal enhancement has been evidently demonstrated in the past $(11,12,14-16)$, some recent in vitro studies on various gastrointestinal and ovarian cancer cell lines did not show such an effect at clinically relevant elevated temperatures $(17,18)$. Regarding the thermal enhancement of the cytotoxicity of paclitaxel and docetaxel, results of in vitro and in vivo studies have been inconclusive $(3,4,12)$.

The present study examined whether in vitro cytotoxicity of paclitaxel and docetaxel to ovarian cancer cells is increased at higher drug concentrations, supporting their use for intraperitoneal chemotherapy. Moreover, whether the addition of hyperthermia, as in HIPEC, actually increases their cytotoxicity in ovarian cancer cell lines was also investigated. Lack of increase of cytotoxicity may support the use of intraoperative perfusion chemotherapy under normothermic conditions, avoiding the potential adverse effects of hyperthermia, which will be discussed further on.

\section{Materials and Methods}

Cell lines and culture. Cisplatin-resistant SKOV-3 and OVCAR-3 ovarian cancer cell lines, obtained from the American Type Tissue Culture Collection (Manassas, VA, USA), were maintained at $37^{\circ} \mathrm{C}$ in a humidified atmosphere containing $5 \% \mathrm{CO}_{2}$. SKOV-3 cells were cultured in McCoy's 5A modified medium supplemented with $10 \%$ heat-inactivated fetal bovine serum and OVCAR-3 cells in RPMI1640 medium without phenol red, supplemented with $20 \%$ heat-inactivated fetal bovine serum, $50 \mathrm{IU} \mathrm{ml}^{-1}$ penicillin and $50 \mu \mathrm{g} \mathrm{ml}^{-1}$ streptomycin. All media were purchased from Biochrom (Berlin, Germany).

Cell treatments. Upon reaching 50-60\% confluence, cells grown on culture dishes were incubated with $0.1,1$ or $3 \mu \mathrm{M}$ paclitaxel $\left(\right.$ Taxol ${ }^{\circledR \text {; }}$; Bristol-Meyer Squibb, New York, NY, USA) or docetaxel (Taxotere ${ }^{\circledR}$; Sanofi-Aventis, Paris, France) diluted in culture medium, at $37^{\circ} \mathrm{C}$ (normothermia) or $41.5^{\circ} \mathrm{C}$ (hyperthermia) for $2 \mathrm{~h}$ in a $\mathrm{CO}_{2}$ incubator. Cells were then washed with fresh medium and incubated in drug-free medium at $37^{\circ} \mathrm{C}$ for up to 7 days. Cells cultured without drugs at $37^{\circ} \mathrm{C}$ were used as controls.

In our experimental protocol, micromolar rather than nanomolar concentrations were chosen to mimic conditions found during intraperitoneal chemotherapy $(19,20)$. Treatment of cells at a temperature of $41.5^{\circ} \mathrm{C}$ for $2 \mathrm{~h}$ mimics the hyperthermic conditions under HIPEC according to the protocol used at our center.

Cell proliferation assays. Cells were grown on 24-well plates and after the various treatments cell proliferation was determined using 3-(4, 5dimethylthiazol-2-yl)-2,5-diphenyltetrazolium bromide (MTT), as specified by the supplier (Sigma Chemical Co, St Louis, MO, USA). The percentages of viable cells were determined by measurement of MTT absorbance and results were expressed as the percentage of viable cells by comparison to the maximal $(100 \%)$ cell proliferation of untreated cultures (no paclitaxel or docetaxel, $37^{\circ} \mathrm{C}$ ). Measurements were performed 1,3 and 7 days after each treatment. All cell proliferation data are the means of nine replicates from three independent experiments.
Cell-cycle analysis. Total, adherent and non-adherent, cells following drug, hyperthermia or physiological culture conditions were analyzed. In brief, adherent cells obtained after trypsinization and centrifugation were combined with non-adherent cells contained in the culture supernatant and the total cell population was washed with culture medium and phosphate-buffered saline. Cells in phosphate-buffered saline were treated in order to stain the DNA using the DNAPrep Coulter Reagent Kit (Beckman Coulter, Brea, CA, USA), as specified by the supplier. Samples were subjected to fluorescence-activated cell sorting flow cytometry in a Coulter Epics Elite (Beckman Coulter). Cellcycle analysis, focused on the $\mathrm{G}_{2} \mathrm{M}$ phase in which malignant cells are arrested by taxanes, was performed 1, 3 and 7 days after each treatment.

Statistical analysis. For differences in cell proliferation between the various experimental treatments, $t$-test analysis with GraphPad Prism 7 Software (San Diego, CA, USA) was performed, while significance of differences in the proportion of cells in the $\mathrm{G}_{2}-\mathrm{M}$ phase after the various experimental treatments were determined with chi square analysis with GraphPad Prism 7 Software. Differences with a $p$-value of less than 0.05 were considered significant.

\section{Results}

Inhibition of cell proliferation with different drug concentrations. Under normothermic conditions, higher concentrations of either paclitaxel or docetaxel overall resulted in significantly reduced cell proliferation in both cell lines $(p<0.05$, Figures 1 and 2$)$. No difference in cytoxicity was observed after 7 days between results under the highest concentrations of docetaxel in both cell lines, most probably because further decrease of an already very low cell proliferation rate would not be feasible.

At $37^{\circ} \mathrm{C}$ docetaxel appeared to be significantly $(p<0.05)$ more effective than paclitaxel in reducing cell proliferation of SKOV-3 cells at all drug concentrations and time points and in OVCAR-3 cells at lower concentrations of 0.1 and $1 \mu \mathrm{M}$ (Figures 1 and 2).

Hyperthermia versus normothermia. Cell proliferation: When comparing the effect of different concentrations of paclitaxel on SKOV-3 cell proliferation under normothermic and hyperthermic conditions (Figure 1), temporary thermal enhancement of the drug effect was observed only for $0.1 \mu \mathrm{M}$ (cell proliferation rate: $99.8 \%$ vs. $88.0 \%, p=0.001$ ) and $1 \mu \mathrm{M}$ paclitaxel $(99.4 \%$ vs. $87.3 \%, p<0.0001)$ at $24 \mathrm{~h}$. At 7 days, no difference in cell proliferation was shown. Data from cell proliferation of OVCAR-3 cells were slightly different when cells were treated with $1 \mu \mathrm{M}$ paclitaxel; a higher cell proliferation rate was observed in hyperthermia-treated cells at $24 \mathrm{~h}(98.5 \%$ vs. 85.3\%, $p=0.014)$, whereas thermal enhancement of paclitaxel effect was shown at 7 days $(37.7 \%$ vs. $23.5 \%, p=0.0023)$. There were no significant differences for other concentrations at the different time points.

In SKOV-3 cells hyperthermia enhanced the effect of docetaxel at $0.1 \mu \mathrm{M}(92.1 \%$ vs. $80.8 \%, p=0.0039)$ and $1 \mu \mathrm{M}$ (93.0\% vs. $79.7 \%, p=0.0004$ ) after $24 \mathrm{~h}$, but not at 7 days 
$37^{\circ} \mathrm{C}$
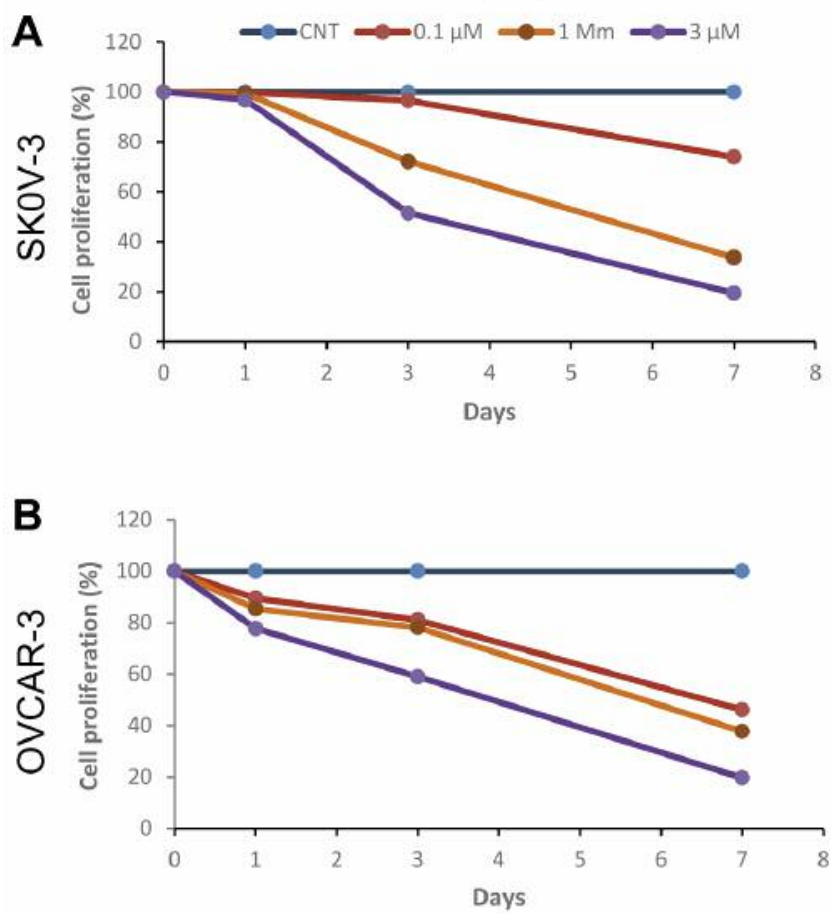
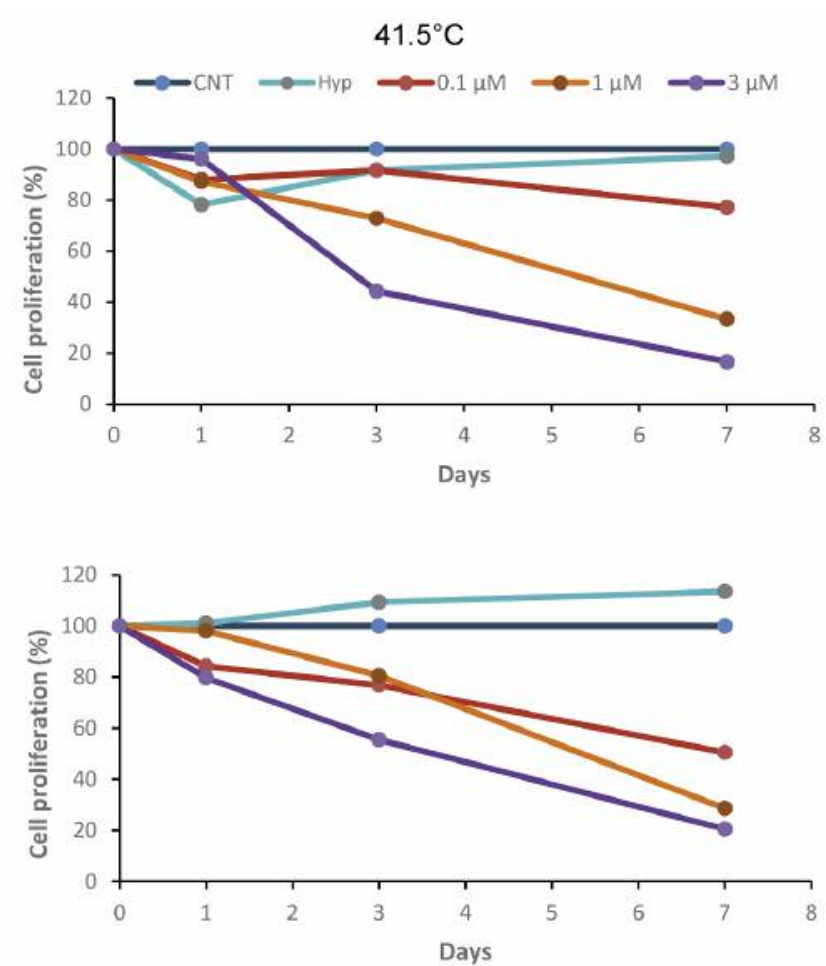

Figure 1. Figure 1. Effect of 2-hour treatment with different concentrations $(0.1,1$ and $3 \mu M)$ of paclitaxel under normothermic (left panel) and hyperthermic (Hyp; right panel) conditions on the proliferation of SKOV-3 (A) and OVCAR-3 (B) cells relative to that of the non-treated cell population $(C N T)$. The treated and untreated cells were cultured under normal conditions for 1, 3 and 7 days. Cell proliferation was measured using MTT assay. For statistical significance of differences among values please see the text.

(Figure 2). A very similar cell proliferation-inhibitory effect was shown in cells treated only with hyperthermia. In OVCAR-3 cells, there were no statistically significant differences between the effect of docetaxel under normothermic versus hyperthermic conditions.

Notably, 2-h hyperthermia without drug administration resulted in an increase, although statistically non-significant, of the OVCAR-3 cell proliferation rate at 3 and 7 days, while such a phenomenon was not observed in SKOV-3 cells.

Cell-cycle analysis: Cell-cycle analysis showed a differential effect of treatments on the $\mathrm{G}_{2} / \mathrm{M}$ subpopulation in the two cell lines used (Figure 3).

Seven days after exposure of SKOV-3 cells to $1 \mu \mathrm{M}$ paclitaxel, we found a significant increase of cells in the $G_{2} / M$ phase at hyperthermic comparing to normothermic conditions (14.6\% vs. $0.7 \%, p=0.0003)$. Such a difference was not observed for $1 \mu \mathrm{M}$ docetaxel. Treatment of OVCAR-3 cells with either $1 \mu \mathrm{M}$ paclitaxel or docetaxel under hyperthermic conditions resulted in a significantly higher proportion of cells in the $\mathrm{G}_{2} / \mathrm{M}$-phase at 7 days $(12.6 \%$ vs. $0 \%, p=0.0002$ and $34.9 \%$ vs. $2.6 \%, p<0.0001$, respectively). Notably, exposure to $1 \mu \mathrm{M}$ docetaxel under hyperthermic conditions let to a significantly higher percentage of OVCAR-3 cells in the $\mathrm{G}_{2} / \mathrm{M}$ phase at 7 days in comparison to paclitaxel under the same conditions $(p=0.0004)$.

Exposure of SKOV-3 cells to both paclitaxel, and docetaxel at $3 \mu \mathrm{M}$ under hyperthermic conditions resulted in a significantly higher proportion of cells in the $\mathrm{G}_{2} / \mathrm{M}$-phase at 7 days $(15.2 \%$ vs. $3.3 \%, p=0.0003$ and $15.2 \%$ vs. $1.2 \%$, $p=0.005$, respectively). Similar data were obtained for OVCAR-3 cells (38.6\% vs. $0 \%, p<0,0001$ and $17.7 \%$ vs. $5.1 \%, p=0.015$, respectively). Contrarily to the case of $1 \mu \mathrm{M}$ concentration, exposure to $3 \mu \mathrm{M}$ paclitaxel under hyperthermic conditions let to a significantly higher percentage of OVCAR3 cells in the $\mathrm{G}_{2} / \mathrm{M}$-phase at 7 days than did exposure to docetaxel $(p=0.0016)$.

Overall, our results show that, in general, hyperthermia when combined with drug treatment caused a delay in the $\mathrm{G}_{2} / \mathrm{M}$ phase in comparison to treated cells without hyperthermia, although the percentage of cells in $G_{2} / M$ was very close to that of untreated cells in both cell lines. Interestingly, when OVCAR-3 cells were treated only with hyperthermia, an opposite effect, showing a decrease of the $\mathrm{G}_{2} / \mathrm{M}$ sub-population, was observed at 7 days $(p<0.0001)$. 

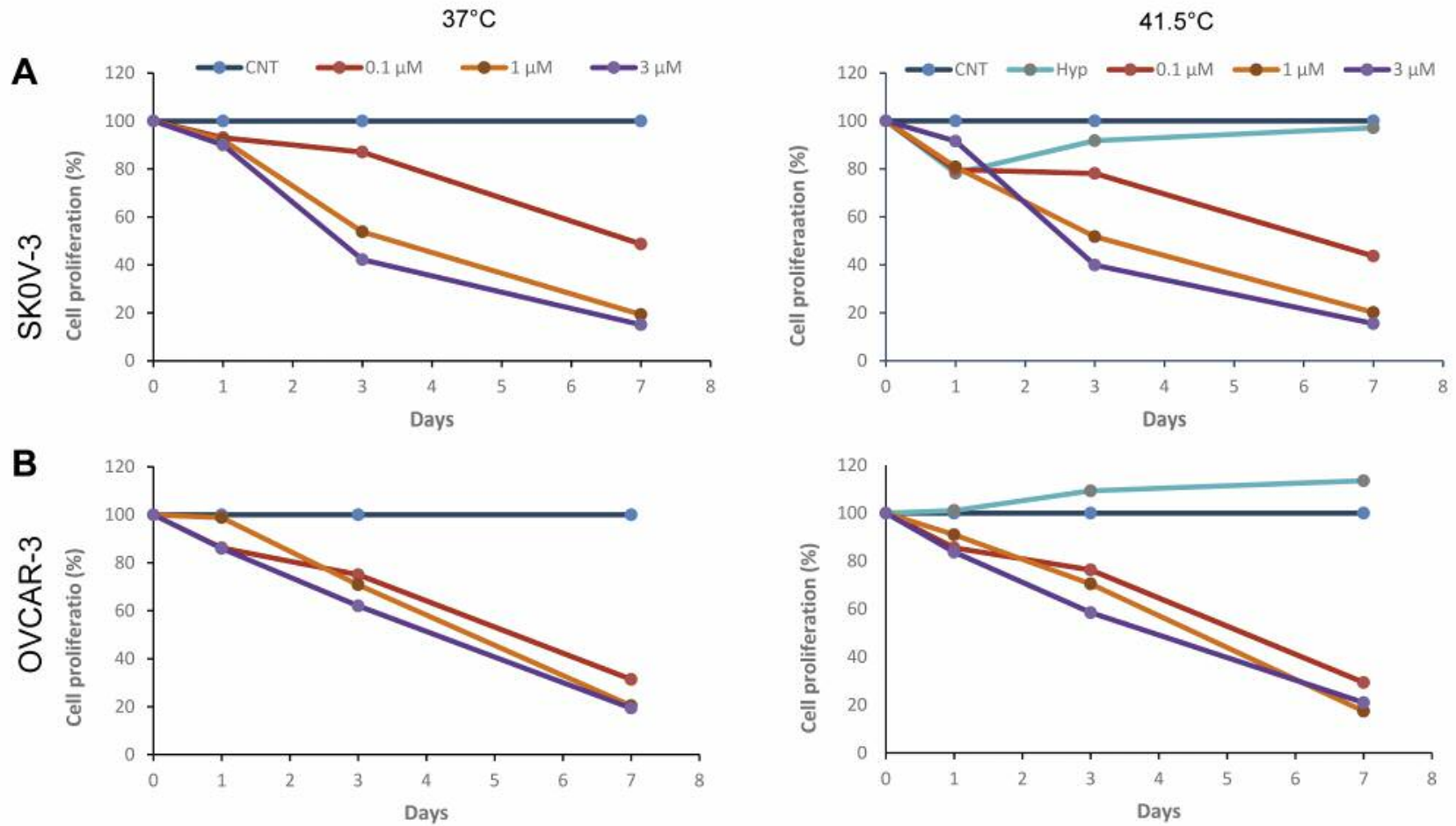

Figure 2. Effect of 2-hour treatment with different concentrations $(0.1,1$ and $3 \mu M)$ of docetaxel under normothermic (left panel) and hyperthermic (Hyp; right panel) conditions on the proliferation of SKOV-3 (A) and OVCAR-3 (B) cells relative to that of the non-treated cell population (CNT). The treated and untreated cells were cultured under normal conditions for 1, 3 and 7 days. Cell proliferation was measured using MTT assay. For statistical significance of differences among values please see the text.

\section{Discussion}

The slow absorption of intraperitoneally delivered paclitaxel and docetaxel from the abdominal cavity, mainly due to their high molecular weight and hydrophobic properties, and their first-pass hepatic metabolism, results in high intraperitoneal drug concentrations and exposure of intraperitoneal tumor cells to these drugs, with simultaneously low systemic drug concentrations and hence limited systemic toxicity $(3,4,19-$ 21). This pharmacokinetic advantage is reflected by the ratio of the areas under the curve for drug concentration versus time for intraperitoneal and intravenous application of 550-2,300 and 150-3,000 for paclitaxel and docetaxel, respectively, and only $15-22$ for platinum compounds $(3,4,19,20)$. As demonstrated in the present and other studies (22), higher paclitaxel and docetaxel concentrations are associated with increased inhibition of cell proliferation. Short-term exposure of cancer cells to high concentrations of taxanes appears effectively to induce long-term inhibition of cell proliferation and cell death. Considering their highly favorable pharmacokinetic profile, their high efficacy against ovarian cancer and the correlation of exposure to treatment response
$(1,2)$, paclitaxel and docetaxel are attractive agents for intraperitoneal chemotherapy in patients with advanced ovarian cancer. The GOG172 randomized trial demonstrated a highly significant survival benefit for the combined postoperative regimen of intraperitoneal chemotherapy including paclitaxel and intravenous chemotherapy versus postoperative intravenous chemotherapy alone after CRS for advanced ovarian cancer (5). Consequently, its postoperative intraperitoneal administration is considered beneficial in the current National Comprehensive Cancer Network guidelines (6). Docetaxel may even be more effective, since in the present study, docetaxel was more cytotoxic than paclitaxel at similar concentrations. In a randomized trial, CRS and HIPEC with cisplatin and paclitaxel appeared superior to CRS alone for recurrent ovarian cancer (23). Other clinical studies also demonstrated encouraging results of HIPEC including paclitaxel or docetaxel for advanced ovarian cancer $(19,24-$ 32 ), while currently both are being used for HIPEC in ongoing randomized trials (NCT02681432, NCT03373058 and NCT04280185) (33).

As mentioned earlier, hyperthermia may be directly cytotoxic and enhance the cytotoxic effect and tissue 
A

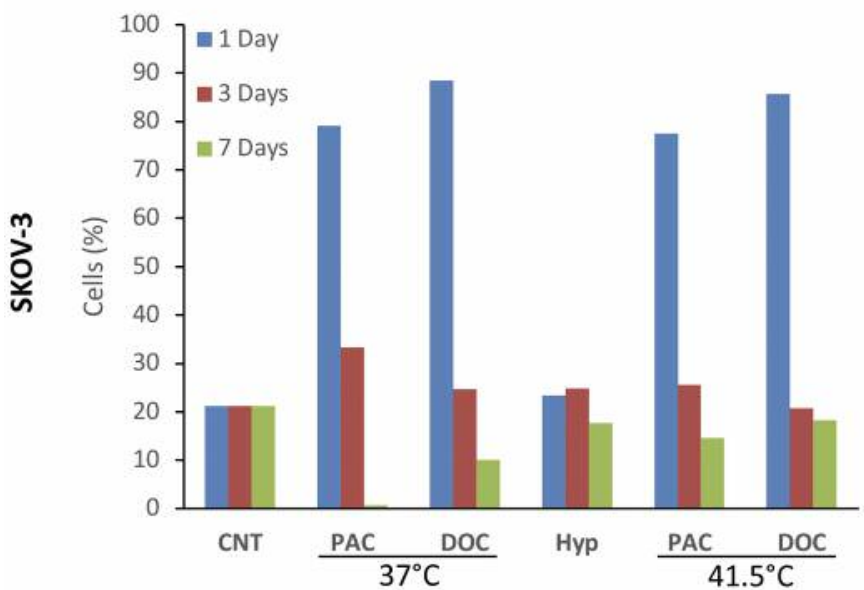

B

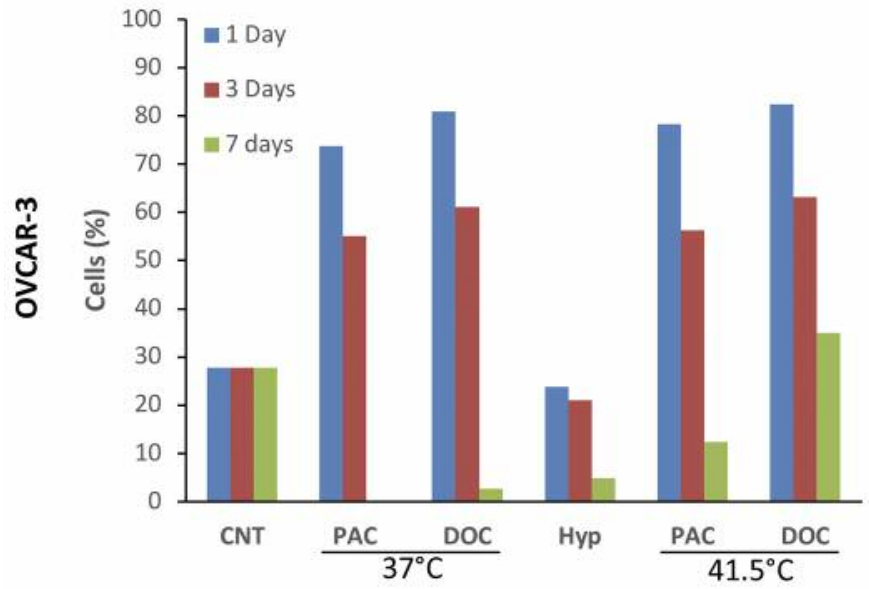

$3 \mu \mathrm{M}$
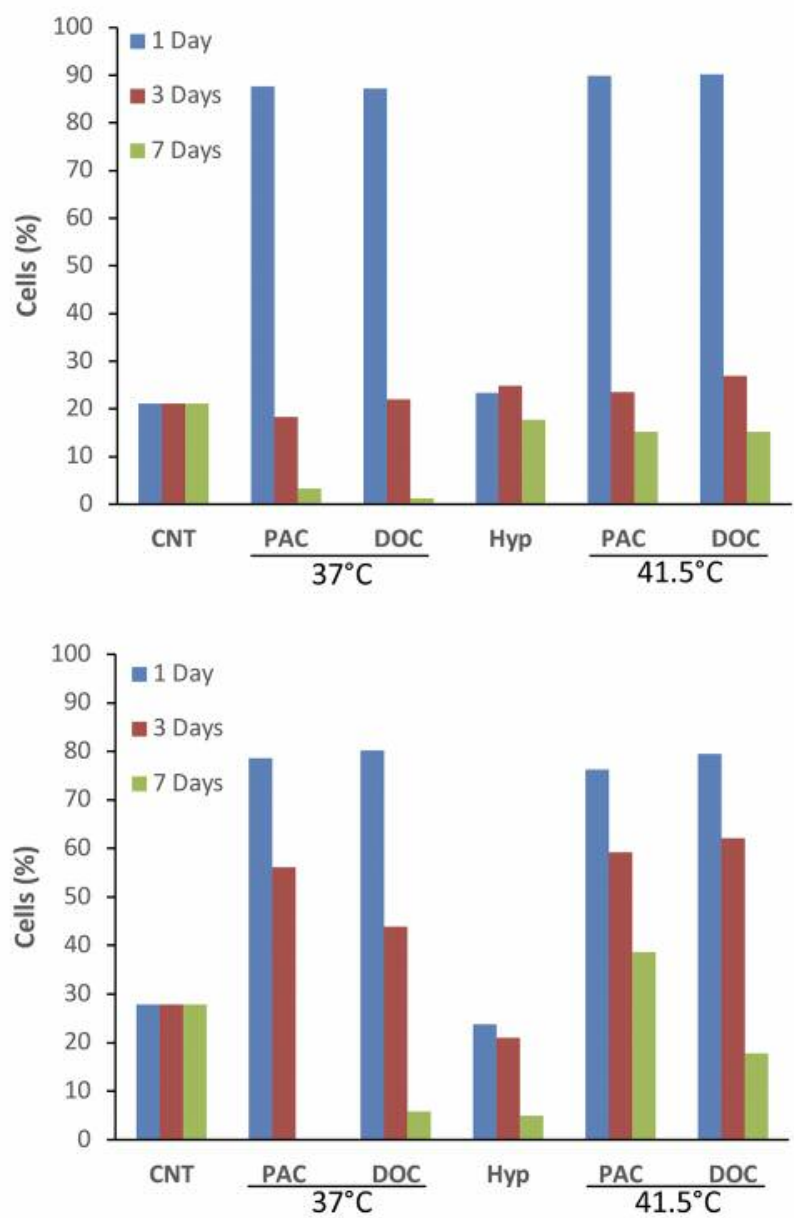

Figure 3. Effect of different treatments on the $G_{2} / M$ subpopulation of SKOV-3 (A) and OVCAR-3 (B) cells. Cells were treated with 1 and $3 \mu M$ paclitaxel (PAC) or docetaxel (DOC) at $37^{\circ} \mathrm{C}$ and $41.5^{\circ} \mathrm{C}$ for $2 \mathrm{~h}$ and then cultured under normal conditions for $24 \mathrm{~h}, 3$ days and 7 days. The total number of cells were analyzed by fluorescence-activated sorting and the percentage of cells in the $G_{2} / M$ phase is presented. For statistical significance of differences among values please see the text.

penetration of chemotherapeutics $(4,7,10-12)$. Moreover, hyperthermia can elicit antitumor immune responses by various mechanisms (34). Despite its potential beneficial cytotoxic effects, the addition of hyperthermia to intraperitoneal chemotherapy may have a negative influence on oncological outcome. In a mouse melanoma model, hyperthermia seemed to cause immunosuppressive effects and subsequently disease progression (35). Moreover, the enhanced systemic release of heat-shock proteins (HSPs) during HIPEC may result in reduced response to hyperthermia as well as chemotherapy (3640). Additionally, HSPs have anti-apoptotic properties and promote tumor cell proliferation, invasiveness and metastatic dissemination $(39,41)$. In an experimental study, paclitaxel totally inhibited the expression of HSP27 in BG-1 ovarian cancer cells (42), suggesting that paclitaxel may neutralize the tumor-promoting effects of hyperthermia. In the present in vitro study, 2-h hyperthermia alone resulted in a decrease of the $\mathrm{G}_{2} / \mathrm{M}$ subpopulation and although statistically non-significant, an increased proliferation rate of OVCAR-3 cells after 3 and 7 days, whereas concurrent administration of paclitaxel and docetaxel seemed generally to abrogate this adverse effect. Although interleukin-6 stimulates immune-mediated tumor control, hyperthermia-induced interleukin-6 release may also promote tumor cell proliferation, survival, angiogenesis, as well as evasion of immune surveillance in the tumor microenvironment (43). In an in vitro study, colon cancer cells that were incubated with 5-fluoruracil or mitomycin-C under hyperthermic condition showed increased cell viability 
compared with normothermic incubation with these agents (39). Using tissue samples from peritoneal metastases of colon cancer before and after HIPEC, cancer cells that were able to survive the cytotoxicity of hyperthermia and chemotherapy demonstrated increased cell viability and proliferation (39).

An additional disadvantage of the use of hyperthermia is the risk of additional morbidity because heat can be harmful to normal tissues and intra-abdominal organs (13). CRS and HIPEC for primary and secondary peritoneal malignancies is associated with significant morbidity, which is often considered to be mainly attributed to the major surgery rather than HIPEC (44). Anastomotic leakage, especially in combination with chemotherapy-induced neutropenia, contributes considerably to its morbidity. In most experimental studies (45-50), HIPEC resulted in impaired healing of intestinal anastomoses. Although this may be primarily due to the intraoperative intraperitoneal chemotherapy rather than the hyperthermia (51), the contribution of hyperthermia may still be significant. In some animal models, local hyperthermia was associated with impaired anastomotic healing $(46,49)$ and in other experimental studies not $(45,50,52,53)$. In a recent study on a rat model, normothermic intraperitoneal chemotherapy with paclitaxel or hyperthermic perfusion with normal saline solution had no negative impact on anastomotic healing but the combination of hyperthermia and intraperitoneal chemotherapy with paclitaxel significantly reduced the mechanical strength of colonic anastomoses (50). Moreover, hyperthermia causes dysfunction of the tight junctions that, together with a single layer of enterocytes, form the intestinal epithelial barrier, resulting in augmented permeation of luminal antigens, endotoxins, and bacteria into the bloodstream (54). Additionally, hyperthermia during HIPEC causes a generalized inflammatory response, as evidenced by rising levels of, among other mediators, interleukin- 6 and procalcitonin, resulting in severe hemodynamic derangements (55). This response to heat mimics conditions as observed during sepsis and septic shock and may contribute to increased operative morbidity and mortality. In a propensity score-matched study, HIPEC when compared with normothermic intraoperative intraperitoneal chemotherapy (NIPEC) with oxaliplatin after CRS in 90 colorectal cancer patients was not associated with statistically significantly increased morbidity and mortality, although trends of increased major complications, cardiovascular complications, infections in general and wound infections were observed (56). Additionally, hyperthermia may increase the drug uptake from the abdominal cavity and cause increased systemic toxicity (56).

A drawback of the addition of hyperthermia to intraperitoneal chemotherapy may be the fact that it has been introduced empirically, without having been the subject of clinical trials and without knowing the ideal target temperature. In a recent, not finally published, small randomized study (NCT02739698) (33), complete pathological response of post- treatment biopsies was not significantly different after HIPEC versus NIPEC with paclitaxel in patients with ovarian cancer. Studies comparing survival outcome of NIPEC with HIPEC with paclitaxel or docetaxel after CRS have not been published to date. In the single published randomized study that compared these treatment modalities, only a subgroup of patients with gastric cancer, serosal invasion and absence of visible peritoneal carcinomatosis exhibited a statistically significant survival benefit after adjuvant HIPEC when compared with NIPEC with mitomycin $\mathrm{C}$ and cisplatin (57). Results of an ongoing randomized trial (NCT02567253) comparing HIPEC with NIPEC with cisplatin after CRS for advanced ovarian cancer are eagerly awaited (33). In an experimental animal study, rats with peritoneal carcinomatosis from colorectal origin treated by CRS lived longer after NIPEC than HIPEC with mitomycin-C. Weight loss during the first postoperative days as a marker of treatment-related toxicity was most pronounced in the HIPEC group, while rats which underwent abdominal perfusion with heated normal saline and CRS had significantly higher weight loss than those with CRS alone (58). These findings may suggest additional toxicity of hyperthermia. In recent studies on rats with intra-abdominal inoculation of ovarian cancer, which were however not subjected to CRS, NIPEC with cisplatin was associated with less morbidity and a small, statistically non-significant, increase of survival when compared with HIPEC with cisplatin $(59,60)$.

In the absence of similar studies for taxanes, we have to rely on experimental in vivo and in vitro studies of their thermal enhancement. Their association with hyperthermia is interesting because tubulin/microtubule complex seems to be temperature-dependent (61). Moreover, hyperthermia resulted in an increase of the microtubule polymer mass in toads (62), and in spontaneous tubulin polymerization in sea urchin eggs (63). As already mentioned, paclitaxel may neutralize the eventual tumor-promoting effects of hyperthermia by total inhibition of HSP27 expression in ovarian cancer (42). As shown in Tables I and II, the data on the phenomenon of thermal enhancement for paclitaxel and docetaxel are inconsistent. The experimental studies varied in degree, duration and timing of hyperthermia, drug concentration and exposure time, time of cytotoxicity measurement after treatment, and cell type studied. In two studies, a statistically significant inhibition of drug cytotoxicity was even observed when 1-h hyperthermia was concurrently added at the beginning or the middle of 24-h exposure to paclitaxel $(64,65)$. In spite of causing a higher concentration of paclitaxel to be present in heated breast cancer cells, hyperthermia seemed to inhibit paclitaxel-related cell-cycle effects (65). A recent study demonstrated that the synergistic or even inhibition effect on breast cancer cells highly depends on paclitaxel dose and degree of hyperthermia (66). Similarly, in the present study, the existence of any thermal enhancement often depended on drug 
Table I. Experimental studies on the impact of concurrent hyperthermia on paclitaxel activity.

\begin{tabular}{|c|c|c|c|c|c|c|c|c|c|}
\hline Study & Year & $\begin{array}{l}\text { Concentration/ } \\
\text { dose } \\
\text { paclitaxel }\end{array}$ & $\begin{array}{l}\text { Exposure } \\
\text { to } \\
\text { paclitaxel }\end{array}$ & $\begin{array}{l}\text { Temp. } \\
{ }^{\circ} \mathrm{C}\end{array}$ & $\begin{array}{l}\text { Hyperthermia } \\
\text { duration, } \\
\text { min }\end{array}$ & $\begin{array}{c}\text { Timing of } \\
\text { hyperthermia }\end{array}$ & Cell type & $\begin{array}{c}\text { Effect } \\
\text { assessed e }\end{array}$ & $\begin{array}{c}\text { Thermal } \\
\text { enhancement }\end{array}$ \\
\hline \multicolumn{10}{|l|}{ In vitro } \\
\hline Rietbroek et al. (64) & 1997 & $1-12 \mu \mathrm{M}$ & $24 \mathrm{~h}$ & 41.8 & 60 & First hour & $\begin{array}{l}\text { Rat glial tumor } \\
\text { cells (L-929) }\end{array}$ & 7 Days & No \\
\hline Rietbroek et al. (64) & 1997 & $0.0001-10 \mu \mathrm{M}$ & $1,4,24 \mathrm{~h}$ & 43 & 60 & $\begin{array}{c}\text { First or } \\
\text { last hour }\end{array}$ & $\begin{array}{l}\text { Human squamous } \\
\text { lung cancer } \\
\text { (SW1573) and } \\
\text { murine rhabdomyo- } \\
\text { sarcoma cells (R1) }\end{array}$ & 8-12 Days & No \\
\hline Leal et al. (65) & 1999 & $5,10,100 \mathrm{nM}$ & $24 \mathrm{~h}$ & 43 & 60 & $\begin{array}{l}\text { Start, } \\
\text { middle } \\
\text { or end }\end{array}$ & $\begin{array}{l}\text { Human breast } \\
\text { adenocarcinoma } \\
\text { cells (MCF-7) }\end{array}$ & $26 \mathrm{H}$ & No \\
\hline van Bree et al. (71) & 2000 & $\begin{array}{c}2,10,30 \\
100 \mathrm{nM}\end{array}$ & $24 \mathrm{~h}$ & 41 & 60 & Last hour & $\begin{array}{l}\text { Various human } \\
\text { colorectal cancer } \\
\text { cell lines }\end{array}$ & 10-12 Days & No \\
\hline Othman et al. (72) & 2001 & $10 \mu \mathrm{M}$ & $2 \mathrm{~h}$ & 43 & 60 & Last hour & $\begin{array}{l}\text { Murine breast } \\
\text { cancer cells } \\
\text { (FM3A) }\end{array}$ & $\begin{array}{c}1,2 \text { and } \\
24 \mathrm{H}\end{array}$ & Yes \\
\hline Michalakis et al. (73) & 2005 & $10-20 \mu \mathrm{M}$ & $2 \mathrm{~h}$ & $41.5,43$ & 120 & $\begin{array}{l}\text { Entire } \\
\text { paclitaxel } \\
\text { exposure }\end{array}$ & $\begin{array}{l}\text { Human cervical } \\
\text { cancer cells } \\
(\mathrm{HeLa})\end{array}$ & $\begin{array}{l}3 \text { and } \\
7 \text { Days }\end{array}$ & No \\
\hline Michalakis et al. (79) & 2007 & $10-20 \mu \mathrm{M}$ & $2 \mathrm{~h}$ & $41.5,43$ & 120 & $\begin{array}{l}\text { Entire } \\
\text { paclitaxel } \\
\text { exposure }\end{array}$ & $\begin{array}{c}\text { Human mammary } \\
\text { (MCF-7), ovarian } \\
\text { (SKOV-3) and } \\
\text { liver cancer } \\
\text { (HEpG2) cells }\end{array}$ & $\begin{array}{l}3 \text { and } \\
7 \text { Days }\end{array}$ & Yes/No* \\
\hline Muller et al. (22) & 2012 & $0.11-0.88 \mu \mathrm{M}$ & $\begin{array}{l}30,60 \\
90 \mathrm{~min}\end{array}$ & $38-43$ & $30,60,90$ & $\begin{array}{c}\text { Entire } \\
\text { paclitaxel } \\
\text { exposure }\end{array}$ & $\begin{array}{l}\text { Human ovarian } \\
\text { cancer cells } \\
\text { (SHIN-3) }\end{array}$ & 10 Days & No \\
\hline Lin et al. (69) & 2013 & $2-100 \mathrm{nM}$ & $24 \mathrm{~h}$ & 41 & $2 \times 120$ & $\begin{array}{l}\text { At start and } \\
\text { after } 24 \mathrm{~h}\end{array}$ & $\begin{array}{l}\text { Human breast } \\
\text { cancer cells } \\
(\mathrm{MCF}-7)\end{array}$ & $\begin{array}{c}12,24, \\
36,48 \mathrm{H}\end{array}$ & Yes** \\
\hline Liao et al. (66) & 2019 & 5 or $10 \mu \mathrm{g} / \mathrm{ml}$ & $2 \mathrm{~h}$ & $40,40.5,41$ & 120 & $\begin{array}{c}\text { Entire } \\
\text { paclitaxel } \\
\text { exposure }\end{array}$ & $\begin{array}{l}\text { Human breast } \\
\text { cancer cells } \\
(\mathrm{MCF}-7)\end{array}$ & 24 and $48 \mathrm{H}$ & Yes*** \\
\hline Present study & 2020 & $\begin{array}{c}0.1,1 \text { or } \\
3 \mu \mathrm{M}\end{array}$ & $2 \mathrm{~h}$ & 41.5 & 120 & $\begin{array}{l}\text { Entire } \\
\text { paclitaxel } \\
\text { exposure }\end{array}$ & $\begin{array}{l}\text { Human ovarian } \\
\text { (SKOV-3 and } \\
\text { OVCAR-3) } \\
\text { cancer cells }\end{array}$ & $\begin{array}{c}1,3, \\
7 \text { Days }\end{array}$ & No**** \\
\hline \multicolumn{10}{|l|}{ In vivo } \\
\hline Cividalli et al. $(74,75)$ & 1999 & $30,45 \mathrm{mg} / \mathrm{kg}$ & $\begin{array}{c}\text { i.p. } \\
\text { injection }\end{array}$ & $41,42,43$ & 60 & $\begin{array}{l}\text { Various, } \\
\text { before and } \\
\text { after }\end{array}$ & $\begin{array}{l}\text { Murine mammary } \\
\text { adenocarcinoma } \\
\text { transplanted in } \\
\text { foot of mice }\end{array}$ & $\begin{array}{l}\text { Clinical } \\
\text { follow-up }\end{array}$ & Yes \\
\hline Mohamed et al. (76) & 2003 & $75,150 \mathrm{mg} / \mathrm{m}^{2}$ & $\begin{array}{c}\text { i.p. } \\
\text { injection }\end{array}$ & 41.5 & 30 & $\begin{array}{l}\text { Just after i.p. } \\
\text { injection }\end{array}$ & $\begin{array}{l}\text { Murine fibro- } \\
\text { sarcoma cells } \\
\text { (FSa-II) injected } \\
\text { in foot of mice }\end{array}$ & $\begin{array}{l}\text { Clinical } \\
\text { follow-up }\end{array}$ & No \\
\hline Boissenot et al. (77) & 2017 & $5 \mathrm{mg} / \mathrm{kg}$ & $\begin{array}{c}i . v . \\
\text { injection }\end{array}$ & $41-43$ & 10 & $\begin{array}{c}\text { Day } 1,3 \\
\text { and } 7\end{array}$ & $\begin{array}{c}\text { CT-26 colon } \\
\text { cancer injected } \\
\text { in flank of mice }\end{array}$ & $\begin{array}{l}\text { Follow-up } \\
13 \text { days }\end{array}$ & Yes \\
\hline
\end{tabular}

Temp.: Temperature; i.p.: intraperitoneal; i.v.: intravenous. \#Relative to exposure to paclitaxel; \#\# and 24 or $48 \mathrm{~h}$ after exposure to paclitaxel; \#\#\#1 $\mathrm{h}$ hyperthermia at beginning, middle or end of treatment with paclitaxel; \#\#\#\# at last hour of exposure to paclitaxel; * only at $43^{\circ} \mathrm{C}$ in $\mathrm{MCF}-7$, not in SKOV-3 cell line; ${ }^{* *}$ only for $10-25 \mathrm{nM}$ after $48 \mathrm{~h}$; $* * *$ however, $5 \mu \mathrm{g} / \mathrm{ml}$ at $40^{\circ} \mathrm{C}$ resulted in enhanced cell proliferation when compared with $37^{\circ} \mathrm{C}$; ****at 7 days, except for $1 \mu \mathrm{M}$ in OVCAR-3 cell line. 
Table II. Experimental studies on the impact of concurrent hyperthermia on docetaxel activity.

\begin{tabular}{|c|c|c|c|c|c|c|c|c|c|}
\hline \multirow[t]{2}{*}{ Study } & \multirow[t]{2}{*}{ Year } & \multirow{2}{*}{$\begin{array}{c}\text { Concentration/ } \\
\text { dose } \\
\text { docetaxel }\end{array}$} & \multirow{2}{*}{$\begin{array}{l}\text { Exposure } \\
\text { to } \\
\text { docetaxel }\end{array}$} & \multirow{2}{*}{$\begin{array}{c}\text { Temp., } \\
{ }^{\circ} \mathrm{C}\end{array}$} & \multicolumn{2}{|c|}{ Hyperthermia ${ }^{\#}$} & \multirow[t]{2}{*}{ Cell type } & \multirow{2}{*}{$\begin{array}{l}\text { Assessment } \\
\text { of } \\
\text { effect }\end{array}$} & \multirow{2}{*}{$\begin{array}{l}\text { Thermal } \\
\text { enhancement }\end{array}$} \\
\hline & & & & & $\begin{array}{l}\text { Duration, } \\
\text { min }\end{array}$ & Timing & & & \\
\hline \multicolumn{10}{|l|}{ In vitro } \\
\hline Rietbroek et al. (64) & 1997 & $0.1-1.2 \mu \mathrm{M}$ & $24 \mathrm{~h}$ & 41.8 & 60 & First hour & $\begin{array}{l}\text { Rat glial tumor } \\
\text { cells (L-929) }\end{array}$ & 7 Days & No \\
\hline Dumontet et al. (68) & 1998 & $50 \mathrm{nM}$ & $60 \mathrm{~min}$ & 43 & 60 & $\begin{array}{c}\text { Entire } \\
\text { docetaxel } \\
\text { exposure }\end{array}$ & $\begin{array}{c}\text { Human erythro- } \\
\text { leukemia (K562) } \\
\text { and sarcoma } \\
\text { cells (MESSA) }\end{array}$ & 3 Days & No \\
\hline Istomin et al. (78) & 2008 & $10-25 \mathrm{ng} / \mathrm{ml}$ & $60 \mathrm{~min}$ & 42 & 60 & $\begin{array}{c}\text { Entire } \\
\text { docetaxel } \\
\text { exposure }\end{array}$ & $\begin{array}{c}\text { Human cervical } \\
\text { cancer cells }(\mathrm{HeLa})\end{array}$ & 2 Days & No \\
\hline Muller et al. (22) & 2012 & $0.78-200 \mathrm{nM}$ & $\begin{array}{l}30,60 \\
90 \mathrm{~min}\end{array}$ & $38-43$ & $\begin{array}{l}30,60 \\
\quad 90\end{array}$ & $\begin{array}{l}\text { Entire } \\
\text { paclitaxel } \\
\text { exposure }\end{array}$ & $\begin{array}{c}\text { Human ovarian } \\
\text { cancer cells } \\
\text { (SHIN-3) }\end{array}$ & 10 Days & $\mathrm{No}^{*}$ \\
\hline Wu et al. (70) & 2017 & $52 \mathrm{nM}$ & $24 \mathrm{~h}$ & 42 & 20 & First $20 \mathrm{~min}$ & $\begin{array}{l}\text { Human prostate } \\
\text { cancer cells (PC-3) }\end{array}$ & 3 Days & Yes \\
\hline Present study & 2020 & $\begin{array}{c}0.1,1 \text { or } \\
3 \mu \mathrm{M}\end{array}$ & $2 \mathrm{~h}$ & 41.5 & 120 & $\begin{array}{c}\text { Entire } \\
\text { paclitaxel } \\
\text { exposure }\end{array}$ & $\begin{array}{c}\text { Human ovarian } \\
\text { cancer (SKOV-3 and } \\
\text { OVCAR-3) cells }\end{array}$ & 1, 3, 7 Days & No \\
\hline \multicolumn{10}{|l|}{ In vivo } \\
\hline Mohamed et al. (76) & 2003 & $\begin{array}{c}175 \text { and } \\
350 \mathrm{mg} / \mathrm{m}^{2}\end{array}$ & $\begin{array}{c}\text { i.p. } \\
\text { injection }\end{array}$ & 41.5 & 30 & $\begin{array}{l}\text { Just after } \\
\text { i.p. injection }\end{array}$ & $\begin{array}{l}\text { Murine fibrosarcoma } \\
\text { cells (FSa-II) } \\
\text { injected in the } \\
\text { foot of mice }\end{array}$ & $\begin{array}{l}\text { Clinical } \\
\text { follow-up }\end{array}$ & Yes \\
\hline Mohamed et al. (67) & 2004 & $350 \mathrm{mg} / \mathrm{m}^{2}$ & $\begin{array}{c}\text { i.p. } \\
\text { injection }\end{array}$ & $\begin{array}{l}41.5 \\
43.5\end{array}$ & 30,90 & $\begin{array}{l}\text { After and/or } \\
3 \mathrm{~h} \text { after } \\
\text { injection }\end{array}$ & $\begin{array}{l}\text { Murine fibrosarcoma } \\
\text { cells (FSa-II) } \\
\text { injected in the } \\
\text { foot of mice }\end{array}$ & $\begin{array}{l}\text { Clinical } \\
\text { follow-up }\end{array}$ & Yes/No** \\
\hline Wu et al. (70) & 2017 & $75 \mathrm{mg} / \mathrm{m}^{2}$ & $\begin{array}{l}\text { Intratumoral } \\
\text { injection }\end{array}$ & 42 & 20 & $\begin{array}{c}\text { Just after } \\
\text { drug injection }\end{array}$ & $\begin{array}{l}\text { Human prostate } \\
\text { cancer cells } \\
\text { (PC-3) injected } \\
\text { subcutaneously in } \\
\text { the back of mice }\end{array}$ & $\begin{array}{l}\text { MRI at } 7 \\
\text { and } 14 \text { days }\end{array}$ & Yes \\
\hline
\end{tabular}

Temp.: Temperature; i.p.: intraperitoneaI. \#Relative to exposure to docetaxel; *except for a 30-min treatment with docetaxel; **only for 90 min hyperthermia at $41.5^{\circ} \mathrm{C}$ immediately after i.p. injection of paclitaxel.

concentration. Moreover, the timing of heat and its sequencing with drug exposure has been shown to be important for the existence of any synergistic effect $(67,68)$. Furthermore, the timing of treatment assessment is of importance. As shown in our study, an eventual initial inhibitory or synergistic effect may have disappeared 7 days after treatment. Hence, it might be that the synergistic effect of hyperthermia and paclitaxel $(66,69)$ or docetaxel (70) as assessed after 2-3 days in some in vitro studies would have been absent if the effect had been evaluated later, as in our study. Most reported in vitro as well as all in vivo experimental studies simulated treatment with intravenous chemotherapy and local hyperthermia delivered to the area of the tumor by external devices, i.e. long drug exposure and hyperthermia during a short period during or after drug exposure to tumor cells, or used cells of tumors that do not cause peritoneal carcinomatosis (Tables I and II) (64-78). Only in the report of Muller et al. (22) and a previously published study of our center (79), were conditions encountered during HIPEC protocol mimicked, with high drug concentrations, hyperthermia for 30 to 120 minutes, and tumor cell types that do cause peritoneal carcinomatosis (i.e. ovarian cancer cells). Muller et al. did not observe thermal enhancement for both paclitaxel and docetaxel in SHIN-3 human ovarian cancer cells, except for a 30-minute treatment with docetaxel. However, 30minute hyperthermic treatment with docetaxel remained significantly less effective than 60-minute treatment with docetaxel at $37^{\circ} \mathrm{C}(22)$. In a previous study of our center, significant thermal enhancement was not observed for high concentrations of paclitaxel at 41.5 and $43^{\circ} \mathrm{C}$ for $2 \mathrm{~h}$ in SKOV3 ovarian cancer cells (79). There are, however, some 
significant differences between the present and the previously reported study. Firstly, both paclitaxel and docetaxel were used in two different ovarian cancer cell lines (SKOV-3 and OVCAR-3). Furthermore, paclitaxel concentrations were lower than in the previous study, but still high as in HIPEC, to provide more opportunity for additive cytotoxicity of hyperthermia. Since an intra-abdominal temperature of $43^{\circ} \mathrm{C}$ is not usually reached at our center, hyperthermia treatment was performed only at $41.5^{\circ} \mathrm{C}$. In the present study, although a synergistic effect of hyperthermia and paclitaxel or docetaxel was observed after $24 \mathrm{~h}$ in some experiments, this impact did not persist until 7 days after treatment, despite the observation that hyperthermia appeared to result in an increased proportion of cells arrested in the $\mathrm{G}_{2} \mathrm{M}$-phase for a prolonged time. After 7 days, moderate thermal enhancement was only seen with $1 \mu \mathrm{M}$ paclitaxel for OVCAR-3 cells. In a previous study, it was demonstrated that the inhibitory effect on cell proliferation by short exposure to high concentrations of paclitaxel was due both to cell-cycle arrest and cell death. Cell-death mechanisms seemed to be different under hyperthermic compared with normothermic conditions, although necrosis prevailed over apoptosis in both conditions (79).

\section{Conclusion}

The observed in vitro concentration-dependent cytotoxicity of both paclitaxel and, even more effective, docetaxel to ovarian cancer cells support their intraperitoneal use in the treatment of ovarian cancer. The lack of or limited thermal enhancement of their cytotoxicity in this experimental protocol mimicking conditions during HIPEC may suggest similar efficacy for NIPEC. Bearing in mind the above mentioned potentially oncological and treatment-related adverse effects of hyperthermia, further research to assess critically the necessity of hyperthermic conditions in this setting is warranted. Adequate comparative clinical studies will be difficult to perform. A more representative in-vitro model of peritoneal metastases of ovarian cancer with tumor-derived organoids (80, 81) may eventually contribute to determining the role of hyperthermia in intraoperative intraperitoneal chemotherapy with taxanes.

\section{Conflicts of Interest}

The Authors do not have any conflicts of interest to declare in relation to the study.

\section{Authors' Contributions}

EB and PT designed the study. DP, HP and ET performed all experiments. HP, DP and PT analyzed the results. EB, OZ and PT contributed to the interpretation of the results. EB wrote the article with contributions from DM, OZ and PT. All Authors have read and approved the final article.

\section{Acknowledgements}

This study was financially supported by a grant (K.A. 2791) of the Central Health Council at the Ministry of Health of Greece.

\section{References}

1 Stage TB, Bergmann TK and Kroetz DL: Clinical pharmacokinetics of paclitaxel monotherapy: An updated literature review. Clin Pharmacokinet 57: 7-19, 2018. PMID: 28612269. DOI: $10.1007 / \mathrm{s} 40262-017-0563-\mathrm{Z}$

2 Nieuweboer AJ, de Morrée ES, de Graan AJ, Sparreboom A, de Wit R and Mathijssen RH. Inter-patient variability in docetaxel pharmacokinetics: A review. Cancer Treat Rev 41: 605-613, 2015. PMID: 25980322. DOI: 10.1016/j.ctrv.2015.04.012

3 de Bree E, Theodoropoulos PA, Rosing H, Michalakis J, Romanos J, Beijnen JH and Tsiftsis DD: Treatment of ovarian cancer using intraperitoneal chemotherapy with taxanes: From laboratory bench to bedside. Cancer Treat Rev 32: 471-482, 2006. PMID: 16942841. DOI: $10.1016 /$ j.ctrv.2006.07.006

4 de Bree E, Michelakis D, Stamatiou D, Romanos J and Zoras O: Pharmacological principles of intraperitoneal and bidirectional chemotherapy. Pleura Peritoneum 2: 47-62, 2017. PMID: 30911633. DOI: 10.1515/pp-2017-0010.

5 Armstrong DK, Bundy B, Wenzel L, Huang HQ, Baergen R, Lele S, Copeland LJ, Walker JL and Burger RA; Gynecologic Oncology Group: Intraperitoneal cisplatin and paclitaxel in ovarian cancer. N Engl J Med 354: 34-43, 2006. PMID: 16394300. DOI: 10.1056/NEJMoa052985

6 NCCN Clinical Practice Guidelines in Oncology (NCCN Guidelines $\left.{ }^{\circledR}\right)$. Ovarian cancer including fallopian tube cancer and primary peritoneal cancer. Version 1.2020. Available at: https://www.nccn.org/professionals/physician_gls/pdf/ovarian.pdf. [Last accessed on 20th September, 2020]

7 de Bree E and Tsiftsis DD: Principles of perioperative intraperitoneal chemotherapy for peritoneal carcinomatosis. Recent Results Cancer Res 169: 39-51, 2007. PMID: 17506248. DOI: 10.1007/978-3-540-30760-0_4

8 Spiliotis J, Halkia E and de Bree E: Treatment of peritoneal surface malignancies with hyperthermic intraperitoneal chemotherapycurrent perspectives. Curr Oncol 23: e266-e275, 2016. PMID: 27330364. DOI: $10.3747 /$ co.23.2831

9 de Bree E and Michelakis D: An overview and update of hyperthermic intraperitoneal chemotherapy in ovarian cancer. Expert Opinion Pharmacother 21: 1479-1492, 2020. PMID: 32486865. DOI: $10.1080 / 14656566.2020 .1766024$

10 Hildebrandt B, Wust P, Ahlers O, Dieing A, Sreenivasa G, Kerner T, Felix R and Riess H: The cellular and molecular basis of hyperthermia. Crit Rev Oncol Hematol 43: 33-56, 2002. PMID: 12098606. DOI: $10.1016 / \mathrm{s} 1040-8428(01) 00179-2$

11 de Bree E and Tsiftsis DD: Experimental and pharmacokinetic studies in intraperitoneal chemotherapy: From laboratory bench to bedside. Recent Results Cancer Res 169: 53-73, 2007. PMID: 16942841. DOI: $10.1016 /$ j.ctrv.2006.07.006

12 de Bree E: Optimal drugs for HIPEC in different tumors. J BUON 20(1 Suppl): S40-S46, 2015. PMID: 26051331.

13 Yarmolenko PS, Moon EJ, Landon C, Manzoor A, Hochman DW, Viglianti BL and Dewhirst MW: Thresholds for thermal damage to normal tissues: An update. Int J Hyperthermia 27: 320-343, 2011. PMID: 21591897. DOI: 10.3109/02656736.2010.534527 
14 Urano M and Ling CC: Thermal enhancement of melphalan and oxaliplatin cytotoxicity in vitro. Int J Hyperthermia 18: 307-315, 2002. PMID: 12079586 . DOI: 10.1080/02656730210123534

15 Takemoto M, Kuroda M, Urano M, Nishimura Y, Kawasaki S, Kato H, Okumura Y, Akaki S, Kanazawa S, Asaumi J, Joja I and Hiraki Y: The effect of various chemotherapeutic agents given with mild hyperthermia on different types of tumours. Int $\mathbf{J}$ Hyperthermia 19: 193-203, 2003. PMID: 12623641. DOI: 10.1080/0265673021000035235

16 Murata S, Yamamoto H, Shimizu T, Naitoh H, Yamaguchi T, Kaida S, Takebayashi K, Miyake T, Tani T and Tani M: 5-Fluorouracil combined with cisplatin and mitomycin $\mathrm{C}$ as an optimized regimen for hyperthermic intraperitoneal chemotherapy in gastric cancer. J Surg Oncol 117: 671-677, 2018. PMID: 29266509. DOI: $10.1002 /$ jso. 24906

17 Cesna V, Sukovas A, Jasukaitiene A, Naginiene R, Barauskas G, Dambrauskas Z, Paskauskas S and Gulbinas A: Narrow line between benefit and harm: Additivity of hyperthermia to cisplatin cytotoxicity in different gastrointestinal cancer cells. World J Gastroenterol 24: 1072-1083, 2018. PMID: 29563752. DOI: 10.3748/wjg.v24.i10.1072

18 Sukovas A, Cesna V, Jasukaitiene A, Barauskas G, Nadisauskiene RJ, Dambrauskas Z, Paskauskas S and Gulbinas A: Response of OVCAR-3 cells to cisplatin and hyperthermia: Does hyperthermia really matter? Anticancer Res 37: 5011-5018, 2017. PMID: 28870927. DOI: 10.21873/anticanres.11915

19 de Bree E, Rosing H, Filis D, Romanos J, Melisssourgaki M, Daskalakis M, Pilatou M, Sanidas E, Taflampas P, Kalbakis K, Beijnen JH and Tsiftsis DD: Cytoreductive surgery and intraoperative hyperthermic intraperitoneal chemotherapy with paclitaxel: A clinical and pharmacokinetic study. Ann Surg Oncol 15: 1183-1192, 2008. PMID: 18239973. DOI: 10.1245/s10434007-9792-y

20 de Bree E, Rosing H, Beijnen JH, Romanos J, Michalakis J, Georgoulias V and Tsiftsis DD: Pharmacokinetic study of docetaxel in intraoperative hyperthermic i.p. chemotherapy for ovarian cancer. Anticancer Drugs 14: 103-110, 2003. PMID: 12569296. DOI: $10.1097 / 00001813-200302000-00003$

21 Ansaloni L, Coccolini F, Morosi L, Ballerini A, Ceresoli M, Grosso G, Bertoli P, Busci LM, Lotti M, Cambria F, Pisano M, Rossetti D, Frigerio L, D'Incalci M and Zucchetti M: Pharmacokinetics of concomitant cisplatin and paclitaxel administered by hyperthermic intraperitoneal chemotherapy to patients with peritoneal carcinomatosis from epithelial ovarian cancer. Br J Cancer 112: 306-312, 2015. PMID: 25461804. DOI: 10.1038/bjc.2014.602

22 Muller M, Chérel M, Dupré PF, Gouard S, Collet M and Classe JM: The cytotoxic effect of combined hyperthermia and taxane chemotherapy on ovarian cancer cells: results of an in vitro study. Eur Surg Res 48: 55-63, 2012. PMID: 22205139. DOI: $10.1159 / 000333393$

23 Spiliotis J, Halkia E, Lianos E, Kalantzi N, Grivas A, Efstathiou E and Giassas S: Cytoreductive surgery and HIPEC in recurrent epithelial ovarian cancer: A prospective randomized phase III study. Ann Surg Oncol 22: 1570-1575, 2015. PMID: 25391263. DOI: $10.1245 / \mathrm{s} 10434-014-4157-9$

24 Massari R, Barone M, Basilico R, Carella C, Colasante A, De Tursi M, Filippone A, Guetti L and Mani A: Peritonectomy and hyperthermic chemotherapy in patients with advanced or recurrent epithelial ovarian cancer: A single center cohort study. Minerva Chir 69: 17-26, 2014. PMID: 24675243.
25 de Bree E, Romanos J, Michalakis J, Relakis K, Georgoulias V, Melissas $\mathbf{J}$ and Tsiftsis DD: Intraoperative hyperthermic intraperitoneal chemotherapy with docetaxel as second-line treatment for peritoneal carcinomatosis of gynaecological origin. Anticancer Res 23: 3019-3027, 2003. PMID: 12926156.

26 Cascales-Campos PA, Muñoz-Casares FC, Gonzalez-Gil A, Sanchez-Garcia S, Manzanedo I, Morales R, Padilla-Valverde D, Villarejo P, Pereira F, Gil E, Gil J and Spanish Peritoneal Surgical Oncology Group (GECOP): Upfront citorreduction and hyperthermic intraperitoneal chemotherapy with paclitaxel in patients with stage III-C serous epithelial ovarian cancer. Clin Exp Metastasis, 2019. PMID: 31811526. DOI: 10.1007/s10585-01910010-5

27 Manzanedo I, Pereira F, Serrano Á, Pérez-Viejo E, Martínez-Torres B, Carrión L and Calzas J: The use of cisplatin plus doxorubicin or paclitaxel in hyperthermic intraperitoneal chemotherapy (HIPEC) for stage IIIC or IV epithelial ovarian cancer: A comparative study. Clin Transl Oncol 21: 1357-1363, 2019. PMID: 30788835. DOI: 10.1007/s12094-019-02065-3.

28 Muñoz-Casares FC, Medina-Fernández FJ, Arjona-Sánchez Á, Casado-Adam Á, Sánchez-Hidalgo JM, Rubio MJ, Ortega-Salas R, Muñoz-Villanueva MC, Rufián-Peña $S$ and Briceño FJ: Peritonectomy procedures and HIPEC in the treatment of peritoneal carcinomatosis from ovarian cancer: Long-term outcomes and perspectives from a high-volume center. Eur J Surg Oncol 42: 224233, 2016. PMID: 26673283. DOI: 10.1016/j.ejso.2015.11.006

29 Coccolini F, Campanati L, Catena F, Ceni V, Ceresoli M, Jimenez Cruz J, Lotti M, Magnone S, Napoli J, Rossetti D, De Iaco P, Frigerio L, Pinna A, Runnebaum U and Ansaloni L: Hyperthermic intraperitoneal chemotherapy with cisplatin and paclitaxel in advanced ovarian cancer: A multicenter prospective observational study. J Gynecol Oncol 26: 54-61, 2015. PMID: 25376916. DOI: 10.3802/jgo.2015.26.1.54

30 Cascales-Campos PA, Gil J, Gil E, Feliciangeli E, González-Gil A, Parrilla JJ and Parrilla P: Treatment of microscopic disease with hyperthermic intraoperative intraperitoneal chemotherapy after complete cytoreduction improves disease-free survival in patients with stage IIIC/IV ovarian cancer. Ann Surg Oncol 21: 2383-2389, 2014. PMID: 24599409. DOI: 10.1245/s10434-014-3599-4

31 Kim JH, Lee JM, Ryu KS, Lee YS, Park YG, Hur SY, Lee KH, Lee SH and Kim SJ: Consolidation hyperthermic intraperitoneal chemotherapy using paclitaxel in patients with epithelial ovarian cancer. J Surg Oncol 101: 149-155, 2010. PMID: 20035540. DOI: $10.1002 /$ jso. 21448

32 Bae JH, Lee JM, Ryu KS, Lee YS, Park YG, Hur SY, Ahn WS and Namkoong SE: Treatment of ovarian cancer with paclitaxel- or carboplatin-based intraperitoneal hyperthermic chemotherapy during secondary surgery. Gynecol Oncol 106: 193-200, 2007. PMID: 17466362. DOI: 10.1016/j.ygyno.2007.03.019

33 Clinical trials. Available at: https://clinicaltrials.gov/ [Last accessed on 20th September 2020]

34 Toraya-Brown $\mathrm{S}$ and Fiering S: Local tumour hyperthermia as immunotherapy for metastatic cancer. Int J Hyperthermia 30: 531539, 2014. PMID: 25430985. DOI: 10.3109/02656736.2014. 968640

35 Bear AS, Kennedy LC, Young JK, Perna SK, Mattos Almeida JP, Lin AY, Eckels PC, Drezek RA and Foster AE: Elimination of metastatic melanoma using gold nanoshell-enabled photothermal therapy and adoptive T-cell transfer. PLoS One 8: e69073, 2013. PMID: 23935927. DOI: 10.1371/journal.pone.0069073 
36 Kepenekian V, Aloy MT, Magné N, Passot G, Armandy E, Decullier E, Sayag-Beaujard A, Gilly FN, Glehen O and Rodriguez-Lafrasse C: Impact of hyperthermic intraperitoneal chemotherapy on HSP27 protein expression in serum of patients with peritoneal carcinomatosis. Cell Stress Chaperones 18: 623630, 2013. PMID: 23508575. DOI: 10.1007/s12192-013-0415-1

$37 \mathrm{Tu}$ Y, Tian Y, Wu Y and Cui S: Clinical significance of heat shock proteins in gastric cancer following hyperthermia stress: Indications for hyperthermic intraperitoneal chemoperfusion therapy. Oncol Lett 15: 9385-9391, 2018. PMID: 29946371. DOI: 10.3892/ol.2018.8508

38 Pelz JO, Vetterlein M, Grimmig T, Kerscher AG, Moll E, Lazariotou M, Matthes N, Faber M, Germer CT, Waaga-Gasser $\mathrm{AM}$ and Gasser M: Hyperthermic intraperitoneal chemotherapy in patients with peritoneal carcinomatosis: Role of heat-shock proteins and dissecting effects of hyperthermia. Ann Surg Oncol 20: 1105-1113, 2013. PMID: 23456378. DOI: 10.1245/s10434012-2784-6

39 Grimmig T, Moll EM, Kloos K, Thumm R, Moench R, Callies S, Kreckel J, Vetterlein M, Pelz J, Polat B, Tripathi S, Rehder R, Ribas CM, Chandraker A, Germer C-T, Waaga-Gasser AM and Gasser M: Upregulated heat-shock proteins after hyperthermic chemotherapy point to induced cell survival mechanisms in affected tumor cells from peritoneal carcinomatosis. Cancer Growth Metastasis 10: 1179064417730559, 2017. PMID: 29403306. DOI: $10.1177 / 1179064417730559$

40 Cesna V, Sukovas A, Jasukaitiene A, Silkuniene G, Paskauskas S, Dambrauskas Z and Gulbinas A: Stimulated upregulation of HO1 is associated with inadequate response of gastric and ovarian cancer cell lines to hyperthermia and cisplatin treatment. Oncol Lett 18: 1961-1968, 2019. PMID: 31423266. DOI: 10.3892/ ol.2019.10489

41 Lianos GD, Alexiou GA, Mangano A, Mangano A, Rausei S, Boni L, Dionigi G and Roukos DH: The role of heat-shock proteins in cancer. Cancer Lett 360: 114-118, 2015. PMID: 25721081. DOI: 10.1016/j.canlet.2015.02.026

42 Tanaka Y, Fujiwara K, Tanaka H, Maehata K and Kohno I: Paclitaxel inhibits expression of heat-shock protein 27 in ovarian and uterine cancer cells. Int J Gynecol Cancer 14: 616-620, 2004. PMID: 15304155. DOI: 10.1111/j.1048-891X.2004.14409.x

43 Fisher DT, Appenheimer MM and Evans SS: The two faces of IL6 in the tumor microenvironment. Semin Immunol 26: 38-47, 2014. PMID: 15304155. DOI: 10.1111/j.1048-891X.2004.14409.x

44 Chua TC, Yan TD, Saxena A and Morris DL: Should the treatment of peritoneal carcinomatosis by cytoreductive surgery and hyperthermic intraperitoneal chemotherapy still be regarded as a highly morbid procedure? A systematic review of morbidity and mortality. Ann Surg 249: 900-907, 2009. PMID: 19474692. DOI: 10.1097/SLA.0b013e3181a45d86

45 Aghayeva A, Benlice C, Bilgin IA, Atukeren P, Dogusoy G, Demir F, Atasoy D and Baca B: The effects of hyperthermic intraperitoneal chemoperfusion on colonic anastomosis: An experimental study in a rat model. Tumori 103: 307-313, 2017. PMID: 28291907. DOI: 10.5301/tj.5000610

46 Li S, Zhang YL, Sun JY, Hua YW and Wu PH: Safe temperature range for intraoperative and early postoperative continuous hyperthermic intraperitoneal perfusion in a swine model of experimental distal gastrectomy with Billroth II reconstruction. J Transl Med 11: 181, 2013. PMID: 23895276. DOI: 10.1186/14795876-11-181
47 Aarts F, Bleichrodt RP, de Man B, Lomme R, Boerman OC and Hendriks $\mathrm{T}$ : The effects of adjuvant experimental radioimmunotherapy and hyperthermic intraperitoneal chemotherapy on intestinal and abdominal healing after cytoreductive surgery for peritoneal carcinomatosis in the rat. Ann Surg Oncol 15: 32993307, 2008. PMID: 18712445. DOI: 10.1245/s10434-008-0070-4

48 Pelz JO, Doerfer J, Decker M, Dimmler A, Hohenberger W and Meyer T: Hyperthermic intraperitoneal chemoperfusion (HIPEC) decrease wound strength of colonic anastomosis in a rat model. Int J Colorectal Dis 22: 941-947, 2007. PMID: 17245567. DOI: 10.1007/s00384-006-0246-y

49 Makrin V, Lev-Chelouche D, Even Sapir E, Paran H, Rabau M and Gutman M: Intraperitoneal heated chemotherapy affects healing of experimental colonic anastomosis: An animal study. J Surg Oncol 89: 18-22, 2005. PMID: 15612012. DOI: 10.1002/jso.20161

50 López-López V, Lynn PB, Gil J, García-Salom M, Gil E, González A, Muñoz IP and Cascales-Campos PA: Effect of paclitaxel-based hyperthermic intraperitoneal chemotherapy (HIPEC) on colonic anastomosis in a rat model. Clin Transl Oncol 21: 505-511, 2019. PMID: 30229392. DOI: 10.1007/s12094-018-1948-7

51 Kanellos D, Pramateftakis MG, Mantzoros I, Zacharakis E, Raptis D, Despoudi K, Zaraboukas T, Koliakos G and Lazaridis H: The effects of the intraperitoneal administration of oxaliplatin and 5FU on the healing of colonic anastomoses: An experimental study. Tech Coloproctol 15(Suppl 1): S111-S115, 2011. PMID: 21953242. DOI: 10.1007/s10151-011-0754-9

52 Shimizu T, Maeta M and Koga S: Influence of local hyperthermia on the healing of small intestinal anastomoses in the rat. Br J Surg 78: 57-59, 1991. PMID: 1998866. DOI: 10.1002/bjs.1800780119

53 Biert J, Seifert W, de Man B, Wobbes T, Hoogenhout J and Hendriks T: Combined preoperative irradiation and local hyperthermia delays early healing of experimental colonic anastomoses. Arch Surg 131: 1037-1042, 1996. PMID: 8857899. DOI: 10.1001/archsurg.1996.01430220031006

54 Dokladny K, Zuhl MN and Moseley PL: Intestinal epithelial barrier function and tight junction proteins with heat and exercise. J Appl Physiol (1985) 120: 692-701, 2016. PMID: 26359485. DOI: 10.1152/japplphysiol.00536.2015

55 Coccolini F, Corbella D, Finazzi P, Brambillasca P, Benigni A, Prussiani V, Ceresoli M, Manfredi R, Poiasina E, Bertoli P, Catena F, Bianchetti A, Bontempelli M, Lorini LF, Sonzogni V and Ansaloni L: Time course of cytokines, hemodynamic and metabolic parameters during hyperthermic intraperitoneal chemotherapy. Minerva Anestesiol 82: 310-319, 2016. PMID: 26184701.

56 Gremonprez F, Gossye H and Ceelen W: Use of hyperthermia versus normothermia during intraperitoneal chemoperfusion with oxaliplatin for colorectal peritoneal carcinomatosis: A propensity score matched analysis. Eur J Surg Oncol 45: 366-70, 2019. PMID: 30243468. DOI: $10.1016 /$ j.ejso.2018.08.023

57 Yonemura Y, de Aretxabala X, Fujimura T, Fushida S, Katayama K, Bandou E, Sugiyama K, Kawamura T, Kinoshita K, Endou Y and Sasaki T: Intraoperative chemohyperthermic peritoneal perfusion as an adjuvant to gastric cancer: Final results of a randomized controlled study. Hepatogastroenterology 48: 17761782, 2001. PMID: 11813623.

58 Klaver YL, Hendriks T, Lomme RM, Rutten HJ, Bleichrodt RP and de Hingh IH: Hyperthermia and intraperitoneal chemotherapy for the treatment of peritoneal carcinomatosis: An experimental study. Ann Surg 254: 125-130, 2011. PMID: 21502859. DOI: 10.1097/SLA.0b013e3182197102 
59 Kireeva GS, Bespalov VG, Belyaeva OA, Senchik KY, Stukov AN, Gafton GI, Guseynov KD and Belyaev AM: Normothermic and hyperthermic intraperitoneal chemoperfusions with cisplatin to treat advanced ovarian cancer in experimental settings. Pathol Oncol Res 23: 459-460, 2017. PMID: 28116562. DOI: 10.1007/s 12253-017-0202-x

60 Bespalov VG, Alvovsky IK, Tochilnikov GV, Stukov AN, Vyshinskaya EA, Semenov AL, Vasilyeva IN, Belyaeva OA, Kireeva GS, Senchik KY, Zhilinskaya NT, Von JD, Krasilnikova LA, Alexandrov VA, Khromov-Borisov NN, Baranenko DA and Belyaev AM: Comparative efficacy evaluation of catheter intraperitoneal chemotherapy, normothermic and hyperthermic chemoperfusion in a rat model of ascitic ovarian cancer. Int $\mathbf{J}$ Hyperthermia 34: 545-550, 2018. PMID: 28893108. DOI: $10.1080 / 02656736.2017 .1375161$

61 Barton JS, Vandivort DL, Heacock DH, Coffman JA and Trygg KA: Microtubule assembly kinetics. Changes with solution conditions. Biochem J 247: 505-511, 1987. PMID: 3426549. DOI: 10.1042/bj2470505

62 Alvarez J and Fadić R: Assembly and disassembly of axonal microtubules of the toad Xenopus laevis under the effect of temperature. J Exp Zool 264: 261-266, 1992. PMID: 1431786. DOI: $10.1002 /$ jez.1402640305

63 Harris PJ, Clason EL and Prier KR: Tubulin polymerization in unfertilized sea-urchin eggs induced by elevated temperature. J Cell Sci 93: 9-17, 1989. PMID: 2693467.

64 Rietbroek RC, Katschinski DM, Reijers MH, Robins HI, Geerdink A, Tutsch K, d'Oleire F and Haveman J: Lack of thermal enhancement for taxanes in vitro. Int J Hyperthermia 13: 525-533, 1997. PMID: 9354937. DOI: 10.3109/02656739709023551

65 Leal BZ, Meltz ML, Mohan N, Kuhn J, Prihoda TJ and Herman TS: Interaction of hyperthermia with taxol in human MCF-7 breast adenocarcinoma cells. Int J Hyperthermia 15: 225-236, 1999. PMID: 10365690. DOI: 10.1080/026567399285747

66 Liao S, Hu X, Liu Z, Lin Y, Liang R, Zhang Y, Li Q, Li Y and Liao $\mathrm{X}$ : Synergistic action of microwave-induced mild hyperthermia and paclitaxel in inducing apoptosis in the human breast cancer cell line MCF-7. Oncol Lett 17: 603-605, 2019. PMID: 30655807. DOI: 10.3892/ol.2018.9629

67 Mohamed F, Stuart OA, Glehen O, Urano M and Sugarbaker PH: Docetaxel and hyperthermia: Factors that modify thermal enhancement. J Surg Oncol 88: 14-20, 2004. PMID: 15384091. DOI: $10.1002 /$ jso.20117

68 Dumontet C, Bodin F and Michal Y: Potential interactions between antitubulin agents and temperature: implications for modulation of multidrug resistance. Clin Cancer Res 4: 1563-1566, 1998. PMID: 9626478

69 Lin Y, Liu Z, Li Y, Liao X, Liao S, Cen S, Yang L, Wei J and Hu $\mathrm{X}$ : Short-term hyperthermia promotes the sensitivity of MCF-7 human breast cancer cells to paclitaxel. Biol Pharm Bull 36: 376833, 2013. PMID: 23229357. DOI: 10.1248/bpb.b12-00774

70 Wu X, Zhang F, Hu P, Chen L, Han G, Bai W, Luo J, Chen R, Zhou Y, Sun J and Yang X: Radiofrequency heat-enhanced direct intratumoral chemotherapy for prostate cancer. Oncol Lett 14: 7250-7256, 2017. PMID: 29250164. DOI: 10.3892/ol.2017.7145

71 van Bree C, Savonije JH, Franken NA, Haveman J and Bakker PJ: The effect of p53-function on the sensitivity to paclitaxel with or without hyperthermia in human colorectal carcinoma cells. Int $\mathbf{J}$ Oncol 16: 739-744, 2000. PMID: 10717242. DOI: 10.3892/ ijo.16.4.739
72 Othman T, Goto S, Lee JB, Taimura A, Matsumoto T and Kosaka M: Hyperthermic enhancement of the apoptotic and antiproliferative activities of paclitaxel. Pharmacology 62: 208-12, 2001. PMID: 11359996. DOI: 10.1159/000056096

73 Michalakis J, Georgatos SD, Romanos J, Koutala H, Georgoulias V, Tsiftsis D and Theodoropoulos PA: Micromolar taxol, with or without hyperthermia, induces mitotic catastrophe and cell necrosis in HeLa cells. Cancer Chemother Pharmacol 56: 615-622, 2005. PMID: 16025289. DOI: 10.1007/s00280-005-1002-7

74 Cividalli A, Cruciani G, Livdi E, Pasqualetti P and Tirindelli Danesi: Hyperthermia enhances the response of paclitaxel and radiation in a mouse adenocarcinoma. Int J Radiat Oncol Biol Phys 44: 407-412, 1999. PMID: 10760437. DOI: 10.1016/s03603016(99)00008-5

75 Cividalli A, Livdi E, Ceciarelli F, Piscitelli M, Pasqualetti P, Cruciani G and Tirindelli Danesi D: Hyperthermia and paclitaxelepirubicin chemotherapy: Enhanced cytotoxic effect in a murine mammary adenocarcinoma. Int J Hyperthermia 16: 61-71, 2000. PMID: 10669317. DOI: 10.1080/026567300285420

76 Mohamed F, Marchettini P, Stuart OA, Urano M and Sugarbaker PH: Thermal enhancement of new chemotherapeutic agents at moderate hyperthermia. Ann Surg Oncol 10: 463-468, 2003. PMID: 12734097. DOI: 10.1245/aso.2003.08.006

77 Boissenot T, Bordat A, Larrat B, Varna M, Chacun H, Paci A, Poinsignon V, Fattal E and Tsapis N: Ultrasound-induced mild hyperthermia improves the anticancer efficacy of both Taxol ${ }^{\circledR}$ and paclitaxel-loaded nanocapsules. J Control Release 264: 219-227, 2017. PMID: 28867377. DOI: 10.1016/j.jconrel.2017.08.041

78 Istomin YP, Zhavrid EA, Alexandrova EN, Sergeyeva OP and Petrovich SV: Dose enhancement effect of anticancer drugs associated with increased temperature in vitro. Exp Oncol 30: 5659, 2008. PMID: 18438342 .

79 Michalakis J, Georgatos SD, de Bree E, Polioudaki H, Romanos J, Georgoulias V, Tsiftsis DD and Theodoropoulos PA: Short-term exposure of cancer cells to micromolar doses of paclitaxel, with or without hyperthermia, induces long-term inhibition of cell proliferation and cell death in vitro. Ann Surg Oncol 14: 12201228, 2007. PMID: 17206477. DOI: 10.1245/s10434-006-9305-4

80 Ubink I, Bolhaqueiro ACF, Elias SG, Raats DAE, Constantinides A, Peters NA, Wassenaar ECE, de Hingh IHJT, Rovers KP, van Grevenstein WMU, Laclé MM, Kops GJPL, Borel Rinkes IHM and Kranenburg O: Organoids from colorectal peritoneal metastases as a platform for improving hyperthermic intraperitoneal chemotherapy. Br J Surg 106: 1404-1414, 2019. PMID: 31197820. DOI: 10.1002/bjs.11206

81 Roy P, Canet-Jourdan C, Annereau M, Zajac O, Gelli M, Broutin S, Mercier L, Paci A, Lemare F, Ducreux M, Elias D, Malka D, Boige V, Goéré D and Jaulin F: Organoids as preclinical models to improve intraperitoneal chemotherapy effectiveness for colorectal cancer patients with peritoneal metastases: Preclinical models to improve HIPEC. Int J Pharm 531: 143-152, 2017. PMID: 28803938. DOI: 10.1016/j.ijpharm.2017.07.084

Received October 17, 2020

Revised October 282020

Accepted October 29, 2020 